\title{
AS RELAÇÕES ENTRE O MOVIMENTO SINDICAL E OS GOVERNOS PETISTAS (2003-2016)
}

\author{
Cauê Vieira Campos ${ }^{1}$
}

RESUMO: Neste artigo, pretendemos abordar as relações desenvolvidas entre o movimento sindical brasileiro com os governos Lula (2003-2010) e Dilma (2011-2016) do Partido dos Trabalhadores, com foco principal nas centrais sindicais, como representantes da cúpula desse movimento. Partindo da ideia de que a ascensão de Lula ao Planalto Federal é um marco histórico para o país, principalmente para o sindicalismo - como seu grande representante nas décadas de 1980 e 1990. Retomamos as medidas econômicas e políticas do governo que influenciam diretamente no mercado do trabalho e no campo sindical, e como as centrais e sindicatos reagiram a essas medidas. Mas não vemos o movimento sindical como mero reagente das medidas governamentais, mas também parte dele como construtor, do que ficou conhecido "concertação social". Concluímos que neste período houve um processo de institucionalização e aumento do reconhecimento do sindicalismo como interlocutor do Estado, contudo em detrimento da ação direta grevista e aumento do afastamento entre as cúpulas dirigentes e as bases dos trabalhadores. Tendo como resultado a incapacidade de resistência aos ataques promovidos pelo grande capital de forma mais dura a partir de 2016. Fazemos isso, principalmente, através da bibliografia da área, na qual houve vasta discussão sobre essa temática, e dados econômicos, sociais e sindicais.

PALAVRAS-CHAVE: Sindicalismo; Centrais Sindicais; Reorganização Sindical; Governo; PT; CUT.

\footnotetext{
${ }^{1}$ Mestre em Ciências Políticas pelo Instituto de Filosofia e Ciências Humanas da Universidade Estadual de Campinas (IFCH-UNICAMP) e doutorando no mesmo programa de pósgraduação. Professor de Sociologia na rede estadual de ensino de São Paulo. E-mail: cauecampos@uol.com.br
} 


\title{
THE RELATIONS BETWEEN THE TRADE UNION MOVEMENT AND THE PT GOVERNMENTS (2003-2016)
}

\begin{abstract}
In this papper, we intend to address the relations developed between the Brazilian trade union movement and the Lula (2003-2010) and Dilma (2011-2016) governments of the Workers' Party, with a primary focus on the trade union centrals, as representatives of the movement's leadership. Starting from the idea that the rise of Lula to the presidence is a historical landmark for the country, mainly for the trade unionism like its great representative in the decades of 1980 and 1990 . We return to the economic and political measures of the government that directly influence in the market of the and trade unions, and how centrals and unions reacted to these measures. But we do not see trade union movement as merely reacting to government measures, but also part of it as a constructor, of what has become known as "concertação social." We conclude that in this period there was a process of institutionalization and increased recognition of trade unionism as an interlocutor of the State, however to the detriment of direct action and increased separation between the leaders and workers' bases. Resulting in the inability to resist the attacks promoted by big capital in a more difficult way after 2016. We do this, mainly through the bibliography of the area, in which there was a wide discussion on this subject, and the economic, social and unionism datas.
\end{abstract}

KEYWORDS: Trade Unionism; Trade Unionism Centrals; Union Reorganization; Government; PT; CUT.

\section{INTRODUÇÃO}

A vitória de Lula nas eleições presidenciais de 2002 é um marco histórico para o Brasil, principalmente para o campo sindical, afinal, ele e seu partido - o Partido dos Trabalhadores (P'T) - têm suas origens políticas no chamado "novo sindicalismo". Este cenário colocou uma questão basilar para o movimento sindical brasileiro: o que fazer? Adesão irrestrita, ou oposição incondicional, ou, ainda, críticas pontuais a um governo "parceiro"? Dentre essas alternativas, ocorreram diversas respostas pelos diferentes atores sindicais brasileiros. Neste artigo, buscaremos abordar a relação entre os governos petistas e o movimento sindical compreendendo aproximações, afastamentos e as influências mútuas entre os agentes políticos e institucionais envolvidos.

Temáticas, Campinas, 27, (53): 185-224, fev./jun. 2019 
Não há nenhuma novidade nesse intento - por isso, inclusive, há um caráter de revisão bibliográfica da temática -, pois diversos autores vêm tentando fazer isso desde a ascensão de Lula ao governo federal. Ao longo desse período se consolidaram algumas teses explicativas, Paula Marcelino (2017, p.205) sintetiza as principais: 1) aquelas que identificam uma nova elite sindical ou nova classe no poder (OLIVEIRA, 2003; SÓRIA e SILVA, 2011); 2) aquelas que, a partir de uma leitura gramsciana, percebem um "transformismo" da cúpula dirigente do sindicalismo e um processo de cooptação desta pelo governo (DRUCK, 2006; BRAGA, 2010; SOARES, 2013; MATTOS, 2003); 3) e aquelas que notam a conformação de uma nova frente de alianças de classes e frações de classes - alguns chamam de neodesenvolvimentista - da qual o sindicalismo faria parte como sócio menor e a partir disso ele teria se reconfigurado neste novo mercado de trabalho (GALVÃO, 2012; GALVÃO et al, 2015; ARAÚJO e OLIVEIRA, 2011; MARCELINO, 2017 e BOITO 2018²).

Assim, pretendemos abordar a atuação do movimento sindical brasileiro durante o "ciclo petista" - compreendido de 2003 a 2016 - com foco principal nas centrais sindicais buscando retomar, historicamente, a interação entre o sindicalismo de cúpula com o Estado e o mercado brasileiro nestes 13 anos e, ainda, combinando as medidas dos governos Lula e Dilma e o contexto econômico com os impactos e reações do movimento sindical. Desse modo, longe de entender os sindicatos e centrais como uma força reativa/passiva às medidas das classes dominantes, consideramo-nos como força atuante e fundamental no cenário político contemporâneo.

Hoje, 2019, vivemos em cenário inimaginável há seis anos, por exemplo - quando das "Jornadas de Junho" - afinal, Dilma foi "impeachmada" sem crime de responsabilidade, Lula está preso sem provas, Jair Bolsonaro foi eleito e Sergio Moro - principal perseguidor de Lula - nomeado como Ministro da Justiça. Não dormimos em 2003 e acordamos em um 2019 pós-apolítico. Por isso, consideramos que a compreensão do momento em que vivemos é altamente influenciada pelas relações desenvolvidas entre o movimento sindical e os governos petistas entre 2003-2016.

\footnotetext{
${ }^{2}$ As duas últimas referências foram acrescentadas por nós.
} 
Ainda que careça de desenvolvimento, nossa hipótese explicativa é que o processo de institucionalização desenvolvido pelo movimento sindical nas décadas de 1990 e 2000 aliado à desmobilização das bases e da ação direta grevista neste mesmo período deixou os atores sindicais despreparados para resistir aos ataques - como o golpe jurídico parlamentar ${ }^{3}$, a Reforma Trabalhista de Temer de 2017 e a eleição do candidato da extremadireita Bolsonaro. Contudo, foge do escopo deste dossiê a compreensão do pós-PT. Por isso, neste artigo, abordaremos um elemento fundamental desse processo: a institucionalização e reconhecimento do movimento sindical como agente de interlocução do Estado brasileiro.

Para isso, dividiremos o texto cinco partes: 1) uma breve retomada histórica do cenário sindical e econômico na década de 1990 com foco nos últimos anos e no mercado de trabalho reestruturado e neoliberal; 2) o primeiro mandato de Lula (2003-2007) marcado pela ascensão do mesmo ao Palácio do Planalto e o período de "arrumar a casa"; o sindicalismo é chamado para ser agente central do que ficou conhecido como "concertação social”, mas a CUT também passa por um processo de diáspora; 3) o segundo mandato de Lula (2007-2010), com a "casa arrumada", no qual o governo realiza maiores investimentos em desenvolvimento e na área social com foco no Programa de Aceleração do Crescimento (PAC), e também é promulgada a Lei das Centrais Sindicais, provocando a reorganização do sindicalismo brasileiro; 4) os governos Dilma (2011-2016) ${ }^{4}$ nos quais percebemos o intento de efetivação de uma Nova Matriz Econômica, o que, junto com outros motivos, desemboca em sua queda com pouca resistência das centrais sindicais - até então, base de apoio dos governos petistas; e, por fim, 5) uma tentativa de conclusão, retomando o balanço final desse período à luz dos acontecimentos mais recentes.

3 Não aprofundaremos o debate sobre a caracterização do impeachment da Presidenta Dilma Rousseff como golpe, apenas afirmamos que existiu um celeridade seletiva e ausência de crime capaz de decretar o afastamento tendo como artífices dessa manobra o Judiciário e o Parlamento, figurada nas imagens do STF como avalista do processo e Eduardo Cunha como agente.

${ }^{4}$ No trecho dedicado aos governos Dilma condensamos o primeiro e o segundo mandato. Mesmo sabendo que há diferenças substanciais entre os dois períodos, tratá-los em conjunto, como parte de um mesmo processo, facilita-nos compreender o impeachment sofrido por Dilma. 
Entretanto, esta divisão mesmo que, aparentemente, demasiada cronológica, na verdade, obedece a momentos diferentes da relação governo/sindicalismo - principalmente nas centrais sindicais. Por isso, o marco divisório entre Lula 1 e Lula 2 é mais a Lei das Centrais e o PAC do que a própria reeleição de Lula.

\section{DÉCADA DE 1990: REESTRUTURAÇÃO PRODUTIVA E INSTITUCIONALIZAÇÃO DO "NOVO SINDICALISMO"}

A origem do Partidos dos Trabalhadores remonta a um período excepcional da história do sindicalismo brasileiro e quiçá mundial que ficou conhecido como "novo sindicalismo". A adjetivação de "novo" não necessariamente quer dizer que é algo completamente inovador com novas práticas, métodos e estrutura, mas pelo contrário, muito do "velho" sindicalismo ainda permanece. Por isso, o caráter "novo" vem mais da experiência e de lideranças novas que surgem no movimento sindical brasileiro.

Esse movimento eclode quando no dia 12 de maio de 1978 os operários metalúrgicos da Scania de São Bernardo do Campo realizam uma greve pegando de surpresa não só a gerência da empresa, mas também a direção do sindicato e o governo militar, rompendo com um cerco ao movimento sindical desde o início da Ditadura Militar e sendo a primeira greve de massas na década. Assim, esta greve desencadeia diversos outros movimentos grevistas no setor metalúrgico do $\mathrm{ABC}$ paulista e em outras categorias e regiões do país. Dessa forma, este processo representava os limites do "Milagre econômico" e o aprofundamento do desgaste do regime militar, e tem, entre seus desdobramentos organizativos, a criação do PT em 1980 e da Central Única dos Trabalhadores (CUT) em 1983.

\footnotetext{
${ }^{5}$ Para uma análise do movimento sindical nesse período, ver ANTUNES (1988) e MARONI (1982).

${ }^{6}$ Entre 1967-1973, durante a Ditadura Civil-Militar, no âmbito econômico ficou caracterizado por "Milagre Econômico" devido às elevadas taxas de crescimento econômico registrado pelo país. Tendo Delfin Neto afrente do Ministério da Fazenda, o regime militar, buscando legitimação popular, promoveu políticas de incentivo ao desenvolvimento do capital privado no país com obras de infraestrutura, incentivo ao crédito e políticas fiscais e monetárias específicas para esse objetivo.
} 
A partir daí, a crise da Ditadura se aprofunda, o processo de abertura ganha fôlego com a campanha das "Diretas Já!" e o sindicalismo se torna um agente social central no cenário político de tal forma que o maior expoente do sindicalismo brasileiro, Lula, polariza as eleições presidenciais com o candidato da austeridade neoliberal, Fernando Collor. Ao mesmo tempo, a atividade grevista cresce continuamente no país, atingindo 1962 greves em 89 e 1773 em 90 - o maior pico de greves registradas até 2013 .

Deste modo, na contramão do sindicalismo por todo o mundo, aqui no Brasil os sindicatos demonstram sua força e vitalidade na década de 1980, mas o processo de reestruturação produtiva e neoliberalismo na década de 90 têm um alto impacto negativo na organização e vida dos trabalhadores. Todos os índices que podem demonstrar a força dos sindicatos despencam: redução no número de filiados ${ }^{8}$, diminuição quase pela metade das greves em relação à década anterior, o caráter defensivo das greves ${ }^{9}$, maioria dos reajustes abaixo do INPC ${ }^{10}$, etc.

O tamanho do refluxo do movimento sindical era proporcional aos impactos da reestruturação produtiva e do neoliberalismo que precarizam ainda mais o mercado de trabalho brasileiro, já tão frágil para os trabalhadores ${ }^{11}$. Com isso, podemos perceber um processo de

\footnotetext{
7 No Brasil, os levantamentos mais sistemáticos sobre greves são os produzidos pelo Departamento Intersindical de Estatística e Estudos Econômicos (DIEESE) e podem ser consultados em https://www.dieese.org.br/. Assim, todas as taxas de greves arrolados neste artigo tiveram como base o Sistema de Acompanhamento de Greves (SAG) do DIEESE.

${ }^{8}$ Como percebem Ferraz e Bridi (2014), a queda de sindicalização se dá, principalmente, nas categorias impactadas pela reestruturação produtiva, que eram também as principais bases da CUT e da FS: metalúrgicos, bancários, químicos e petroleiros. Mas, ao mesmo tempo, com a conquista do direito à organização sindical pelos servidores públicos na Constituição de 88, cresce a taxa de sindicalização nesse setor, principalmente, na área da educação e saúde.

${ }^{9}$ Nos termos do DIEESE, são defensivas as greves que reivindicam a manutenção ou cumprimento de direitos já previamente conquistados e/ou pagamentos de salários atrasados. ${ }^{10}$ Índice Nacional de Preços ao Consumidor. De acordo com levantamento feito pelo DIEESE, entre 1996-2003 apenas 38,6\% dos acordos ficaram acima do INPC, o que significa perda de poder de compra dos salários.

11 Além do processo de reestruturação produtiva que atinge os trabalhadores em seu local de trabalho com a ampliação do "auto controle", aceleração da produção, estabelecimento de índices de produtividade e outros, também há um processo de desregulamentação dos direitos trabalhistas como a Lei 9601 que institui o contrato flexível, ampliando o contrato
} 
institucionalização da ação sindical conjuntamente com um momento de ataques provenientes de governos e patrões aos trabalhadores.

Primeiramente, nesse sentido de institucionalização, desde 1988, a Constituição permite uma maior participação institucional dos sindicatos o que estimula a parceria entre o sindicalismo e o Estado. Desde sua criação em 1991, a Força Sindical (FS) já buscava promover um sindicalismo de menos confronto - em oposição à CUT - e mais de conciliação com o Estado e capital (TRÓPIA, 2009).

Alguns anos depois, durante os governos Fernando Henrique Cardoso (1995-2002), os índices de desemprego e de empregos informais aumentam (IPEA, 2000) e são implementadas políticas desfavoráveis aos trabalhadores e suas organizações, a exemplo da MP1079/95 que desindexa os salários e da MP1906/97 que desvincula o reajuste do salário mínimo da inflação; assim, dificultam as negociações entre sindicalistas e representantes patronais. Além disso, o governo FHC foi responsável pela forte repressão militar à greve dos petroleiros da Refinaria da REPLAN (Paulínia/SP) em 1995. A partir deste ano, consegue-se perceber a redução das taxas de greve no país, claramente a repressão à greve dos petroleiros não é o único fator e abordamos os demais ao longo do texto; contudo, diversos autores e atores sindicais colocam esta greve como um marco para o sindicalismo brasileiro contra a ação direta. Inclusive, à época estabeleceu-se uma comparação com a Primeira-Ministra inglesa que afirmou ter quebrado a "espinha dorsal" do sindicalismo inglês após a greve dos mineiros (MARTINS e RODRIGUES, 1999).

Ademais, no mercado de trabalho há a ampliação da terceirização (DIEESE, 2012), criando ocupações, significando a criação de um sem número de sindicatos e, ainda, aprofundando a fragmentação do sindicalismo brasileiro. Neste cenário, os sindicatos acabam perdendo seu ímpeto e capacidade de resistência frente ao capital.

Dessa forma, esse processo será percebido por outros autores como Ladosky et al (2014) como uma transformação na CUT-movimento para a

de tempo parcial, e estabelece a flexibilização da jornada de trabalho. Para mais, a Justiça do Trabalho também foi alterada com a eliminação do juiz classista e com a criação de comissões de conciliação prévia e do rito sumário para os conflitos individuais. (ARAUJO e OLIVEIRA, 2014) 
CUT-instituição, ou seja, a atuação enquanto força social se esvai - greves, protestos, manifestações - em nome da atuação na estrutura estatal. Por sua vez, Galvão (2003) considera que a CUT vivia o dilema entre a crítica e a acomodação ao neoliberalismo.

Esta postura aparentemente inofensiva para ação sindical direta, na verdade, cria sindicatos ainda mais atrelados ao Estado podendo enfraquecer o ímpeto combativo das suas lideranças, visto que se tornam elas mesmas administradoras de um tacão do dinheiro estatal - como veremos esse processo se aprofunda a partir de 2003. Demais, acontecendo em um período de arrefecimento das lutas trabalhistas, pode significar ainda maior afastamento das cúpulas sindicais de suas bases de trabalhadores.

O processo de reorganização e revitalização vivido pelo sindicalismo brasileiro na década de 1980 é amplamente conectado ao surgimento, consolidação e fortalecimento da CUT - tornando-se, desde então, a principal central sindical do país. Aqueles que passaram ao largo desse processo acabaram por consolidar-se na FS e, mais para frente (2007), na União Geral dos Trabalhadores (UGT).

Portanto, é neste momento de enfraquecimento do sindicalismo enquanto movimento social e da diminuição dos índices de greves e sindicalização que a principal liderança sindical do país chega ao governo federal com a promessa de colocar fim às reversões neoliberais que vinham sendo aplicadas pelos governos anteriores ${ }^{12}$. Por outro lado, o setor industrial do capital brasileiro acumulava contradições devido à desestruturação industrial ocorrida nos governos FHC, levando setores da burguesia industrial a ampliar os diálogos com a CUT e o PT e, assim, impulsionando ainda mais a perspectiva de ampliação do arco de alianças do PT promovida desde 1989, como percebe Boito (2018).

Assim, a eleição de Lula é algo paradoxalmente novo para o sindicalismo cutista, pois deveria apoiar um governo que é "seu" ao passo que deveria conduzir os trabalhadores à resistência aos ataques neoliberais vindouros. Colocavam-se duas opções ao sindicalismo brasileiro: apoio

\footnotetext{
12 Para maiores informações do impacto da "década neoliberal" no sindicalismo brasileiro, cf. CARDOSO, 2003.
} 
irrestrito aos governos do PT com o perigo de parecer "chapa branca" ou oposição às medidas neoliberais, o que poderia colocar em risco a possibilidade de mitigar as bases do "seu" governo. Enfim, o que foi feito de fato veremos a seguir.

\section{LULA 1 (2003-2006): CONCERTAÇÃO SOCIAL E DIÁSPORA SINDICAL}

Desse modo, Lula chega ao Palácio do Planalto sem qualquer questionamento sobre sua liderança, mas com esperanças diversas sobre seu mandato: de um lado, os trabalhadores esperavam a melhora das condições de vida, o fim da miséria e das desigualdades abissais, e a reversão das medidas neoliberais dos governos antecessores; de outro, o capital financeiro e industrial esperava que Lula e o PT aproveitassem da sua popularidade para implementar as medidas liberalizantes que FHC não conseguiu fazer. No fim, nem tanto ao céu, nem ao inferno.

O próprio governo, ao lançar o PAC 2 em 2010, afirmou que o primeiro mandato de Lula havia sido para "arrumar a casa" (Comitê Gestor do PAC, 2010, p.3), ou seja, foram introduzidas medidas ortodoxas na economia e mais austeras para a classe trabalhadora. Assim, como percebem Araújo e Oliveira (2014), o primeiro governo petista aplica essas medidas atendendo às exigências do mercado financeiro a fim de evitar a possibilidade de desestabilização política - concomitante a uma agenda de forte impacto social, segundo os autores. Dessa forma, o objetivo do governo seria uma "transição sem rupturas".

Em nossa revisão da literatura, conseguimos perceber um acordo sobre a caracterização do primeiro governo Lula como mais ortodoxo e neoliberal (GALVÃO, 2012; BOITO et al, 2014; ARAÚJO e OLIVEIRA, 2014; BRAGA, 2015), retomaremos algumas medidas que podem deixar isso mais nítido. Porém, contraditoriamente, a primeira medida de impacto - positivo - direto ao mercado de trabalho é o arquivamento do PL 5493 que instituía a flexibilização das relações de trabalho com a prevalência do negociado sob o legislado - ou seja, poderia haver acordos coletivos nos quais os representantes sindicais aceitassem condições inferiores às 
previstas por lei $i^{13}$. No entanto, este projeto de lei que estava para ser votado em 2002 - devido à resistência da CUT e dos partidos de oposição e às dificuldades de aprovar um projeto impopular em ano eleitoral - perdeu o caráter de urgência e teve sua tramitação suspensa em 2003.

Entretanto, a grande medida do primeiro mandato de Lula também aconteceu em 2003: a Reforma da Previdência. Assim, aproveitando esse lastro popular, o PT promove um ataque aos direitos dos trabalhadores, tendo como principais vítimas os servidores públicos. Por isso, os sindicatos de servidores públicos organizaram resistências à reforma colocandose contrários à taxação dos inativos ao fim da aposentadoria integral, à paridade entre ativos e inativos, bem como à criação de fundos de pensão. Mas, mesmo com sindicatos pertencentes a suas bases se mobilizando, a CUT se opõe à participação em uma greve com marcha a Brasília, que resulta em um ato de 50 mil na capital federal.

A partir dessa situação, aprofunda-se a crise de diversos setores com a direção majoritária da CUT, a Articulação Sindical, e se inicia o primeiro movimento de diáspora da central. Assim, um importante sindicato nacional, o ANDES ${ }^{14}$, se desfilia da central e setores ligados ao PSTU $^{15}$ também rompem e conformam um nova central, a Conlutas, em $2004^{16}$. Em seguida, outros setores da esquerda radical do PT são expulsos do partido por votarem contra a Reforma e passam ao movimento de construção de um novo partido, culminando no $\mathrm{PSOL}^{17}$ - estes mesmos setores conformaram mais para frente a Intersindical. Posteriormente, abordaremos a história e o perfil dessas centrais - Conlutas e Intersindical - ao abordar o Congresso Nacional da Classe Trabalhadora (CONCLAT) de 2010.

\footnotetext{
${ }^{13}$ Vale ressaltar que o ACE (Acordo Coletivo Especial) - projeto levado pelo Sindicato dos Metalúrgicos do ABC e pela CUT como maneira de enfrentar a crise - também previa isso e a Reforma Trabalhista do governo Temer - implementada em 2017 - institui essa possibilidade nas relações de trabalho brasileiras.

${ }^{14}$ Sindicato Nacional dos Docentes das Instituições de Ensino Superior.

${ }^{15}$ Partidos Socialista dos Trabalhadores Unificados.

${ }^{16}$ Coordenação Nacional de Lutas.

${ }^{17}$ Partido Socialismo e Liberdade.
} 
Ainda no sentido de aproveitar esse lastro político, o PT e o Lula buscam substituir o período de "parceria" de FHC com o sindicalismo como ficou marcado o "sindicalismo cidadão" - pelo período do "diálogo social", visando promover uma "concertação social", isto é, promover as bases de um novo "contrato social" legitimado socialmente. Dessa forma, o governo lançou dois órgãos paritários e tripartites (composto por Estado/governo, patronato e trabalhadores) visando discutir e encaminhar propostas de Reformas da Previdência, Tributária, Trabalhista e Sindical: o Conselho de Desenvolvimento Econômico e Social (CDES) e o Fórum Nacional do Trabalho (FNT). Porém, ambos os organismos tiveram pouca organicidade após o primeiro ano e não conseguiram avançar no que se propuseram.

Logo, as propostas de reformas Trabalhistas e Sindical, que ficaram a cargo do FNT, não produziram consensos. Inclusive, a Reforma Sindical teve resistência dentro da própria CUT. A Frente de Esquerda Socialista (FES) e o Movimento de Trabalhadores pelo Socialismo (MTS) eram contrários por perceberem que, ao invés de dar maior independência dos sindicatos em relação ao Estado, essa reforma concentrava ainda mais poder nas cúpulas sindicais (GALVÃO, 2012). Já a NCST ${ }^{18}$ - central formada por diversas confederações sindicais - era contrária pelo fim de algumas contribuições obrigatórias.

Contudo, a Articulação Sindical e a FS defendiam a reforma mesmo que as mudanças em pauta não correspondessem ao projeto original de nenhuma delas e sairiam fortalecidas na medida em que obteriam reconhecimento legal, capacidade de negociação e recursos financeiros provenientes de uma parcela da contribuição negocial que viria a substituir as contribuições compulsórias então existentes (GALVÃO, 2012). Esse entrave leva o governo a promover um "fatiamento" da Reforma Sindical e a primeira fatia é a Lei 11.648/08 que regulamenta e institucionaliza as Centrais Sindicais, instituindo que 10\% do valor arrecado pelo Imposto Sindical seja destinado às centrais - retomaremos isso a seguir (LADOSKY, 2014).

${ }^{18}$ Nova Central Sindical dos Trabalhadores. 
Tabela 1: Aumento do Salário Mínimo - Brasil (1995-2016)

\begin{tabular}{|c|c|c|c|c|}
\hline ANO & Valor Nominal & Aumento & \multicolumn{1}{c|}{ INPCA } & Aumento Real \\
\hline 1995 & $\mathrm{R} \$ 100,00$ & & & \\
\hline 1996 & $\mathrm{R} \$ 112,00$ & $12,00 \%$ & $21,98 \%$ & $-9,98 \%$ \\
\hline 1997 & $\mathrm{R} \$ 120,00$ & $7,14 \%$ & $9,12 \%$ & $-1,98 \%$ \\
\hline 1998 & $\mathrm{R} \$ 130,00$ & $8,33 \%$ & $4,34 \%$ & $3,99 \%$ \\
\hline 1999 & $\mathrm{R} \$ 136,00$ & $4,62 \%$ & $2,49 \%$ & $2,13 \%$ \\
\hline 2000 & $\mathrm{R} \$ 151,00$ & $11,03 \%$ & $8,43 \%$ & $2,60 \%$ \\
\hline 2001 & $\mathrm{R} \$ 180,00$ & $19,21 \%$ & $5,27 \%$ & $13,94 \%$ \\
\hline 2002 & $\mathrm{R} \$ 200,00$ & $11,11 \%$ & $9,44 \%$ & $1,67 \%$ \\
\hline 2003 & $\mathrm{R} \$ 240,00$ & $20,00 \%$ & $14,74 \%$ & $5,26 \%$ \\
\hline 2004 & $\mathrm{R} \$ 260,00$ & $8,33 \%$ & $10,38 \%$ & $-2,05 \%$ \\
\hline 2005 & $\mathrm{R} \$ 300,00$ & $15,38 \%$ & $6,13 \%$ & $9,25 \%$ \\
\hline 2006 & $\mathrm{R} \$ 350,00$ & $16,67 \%$ & $5,05 \%$ & $11,62 \%$ \\
\hline 2007 & $\mathrm{R} \$ 380,00$ & $8,57 \%$ & $2,81 \%$ & $5,76 \%$ \\
\hline 2008 & $\mathrm{R} \$ 415,00$ & $9,21 \%$ & $5,15 \%$ & $4,06 \%$ \\
\hline 2009 & $\mathrm{R} \$ 465,00$ & $12,05 \%$ & $6,48 \%$ & $5,57 \%$ \\
\hline 2010 & $\mathrm{R} \$ 510,00$ & $9,68 \%$ & $4,11 \%$ & $5,57 \%$ \\
\hline 2011 & $\mathrm{R} \$ 540,00$ & $5,88 \%$ & $6,46 \%$ & $-0,58 \%$ \\
\hline 2012 & $\mathrm{R} \$ 622,00$ & $15,19 \%$ & $6,07 \%$ & $9,12 \%$ \\
\hline 2013 & $\mathrm{R} \$ 678,00$ & $9,00 \%$ & $6,19 \%$ & $2,81 \%$ \\
\hline 2014 & $\mathrm{R} \$ 724,00$ & $6,78 \%$ & $5,56 \%$ & $1,22 \%$ \\
\hline 2015 & $\mathrm{R} \$ 788,00$ & $8,84 \%$ & $6,22 \%$ & $2,62 \%$ \\
\hline 2016 & $\mathrm{R} \$ 880,00$ & $11,68 \%$ & $11,27 \%$ & $0,41 \%$ \\
\hline
\end{tabular}

Fonte: INPC-IBGE - Elaboração Própria

Outro elemento importante para compreensão da interação do sindicalismo com o primeiro mandato de Lula é a política de valorização dos salários. Primeiramente, com o aumento rea ${ }^{19}$ do Salário Mínimo atingindo ${ }^{19}$ Por "aumento real" compreende-se o valor de aumento nominal deduzido do índice de 
$24,08 \%$ no acumulado do primeiro governo. A título de comparação, no último mandato de FHC se acumulou 20,34\% de aumento real; em Lula 1 se teve um aumento médio real de 6,02\% e em FHC 2 de 5,09\%. Nota-se que a diferença não é substancial como será nos anos seguintes, mas já se percebe uma tendência de valorização do Salário Mínimo - como se pode perceber pela linha de tendência.

Autores como Araújo e Oliveira (2014) atribuirão essa política a uma conquista das centrais sindicais, visto que estas realizaram entre 2004 e 2006 três marchas a Brasília para pressionar o governo a aumentar o salário mínimo. A partir de 2008, foi conquistada a vinculação do reajuste do Salário Mínimo à inflação mais a variação do Produto Interno Bruto (PIB) nos dois anos anteriores.

Ademais, outra perspectiva dessa política de valorização da renda do trabalho é perceptível na distribuição dos reajustes salariais em comparação com o INPC-IBGE ${ }^{20}$. Segundo o DIEESE (2017), é notável o crescimento dos acordos acima do INPC, ou seja, de reajustes reais conquistados pelas mais diversas categorias do país. Enquanto em 2002 apenas $25,8 \%$ das negociações coletivas tiveram índices de reajuste acima da inflação, esse percentual atingiu em 2006 86,3\%. Claramente, essa não é uma situação promovida pelo governo diretamente, mas existe uma forte influência deste sobre o processo de negociação dos sindicatos patronais com sindicatos dos trabalhadores, ainda mais em um país com alto nível de atrelamento da estrutura sindical ao Estado, principalmente com os casos de ajuizamentos de greves e dissídios coletivos ${ }^{21}$.

inflação do IPCA (Índice Nacional de Preços ao Consumir Amplo) do ano anterior medido pelo IBGE.

${ }^{20}$ Índice Nacional de Preços ao Consumidor.

${ }^{21}$ No Brasil, o período de data-base é destinado para negociações para estabelecimento dos acordos coletivos por categorias ou empresas - a maior parte das greves ocorrem nestes períodos. Logo, caso o setor patronal e dos trabalhadores não consigam atingir um acordo, podem acionar a Justiça do Trabalho para solução das cláusulas não acordadas anteriormente. Assim, o acordo coletivo é decidido pelos magistrados com uma sensível redução da capacidade de barganha dos trabalhadores. 


\section{Gráfico 1: Aumento real (\%) do Salário Mínimo - Brasil (1996-2016)}

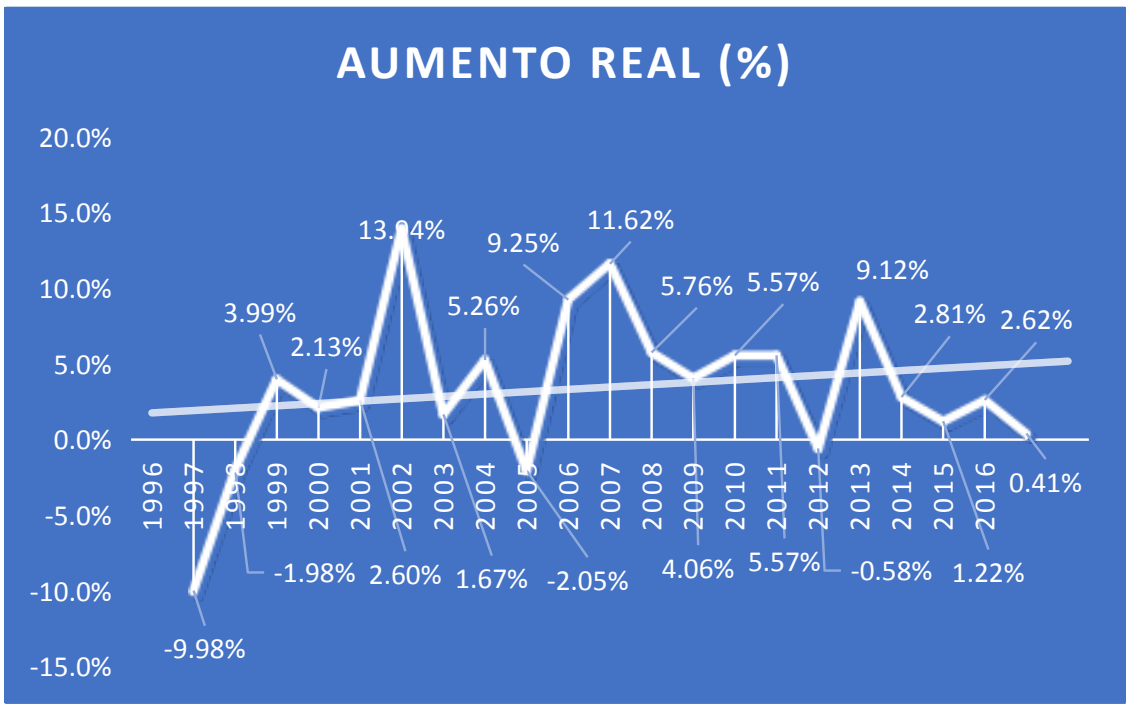

Fonte: INPC-IBGE - Elaboração Própria

Além desses elementos, o primeiro governo de Lula é midiático e politicamente marcado pelo que ficou conhecido como "Mensalão". No campo sindical, centrais à direita da CUT - como a FS, Central Autônoma dos Trabalhadores (CAT), Social Democracia Sindical (SDS) e Centra Geral dos Trabalhadores (CGT) - participam das manifestações organizadas por partidos de oposição exigindo apurações rigorosas e punições aos culpados e, também, cobrando explicações da CUT e seu silencia-mento sobre os casos de corrupção ${ }^{22}$.

\footnotetext{
${ }^{22} \mathrm{Na}$ verdade, a FS e a CGT assinam conjuntamente com a CUT e outros movimentos sociais que apoiavam os governos Lula uma carta da "Coordenação de Movimentos Sociais", na qual alertavam que os setores de oposição se aproveitavam das denúncias de corrupção para, através de um "espetáculo de denuncismo", colocar um "fim prematuro ao governo do primeiro trabalhador eleito Presidente da República”. Ver Revista Força, Ano 12, setembro de 2005.
} 
Gráfico 2: Distribuição dos reajustes salariais, em comparação com o INPC-IBGE, e variação real média dos reajustes - Brasil, 1996-2016

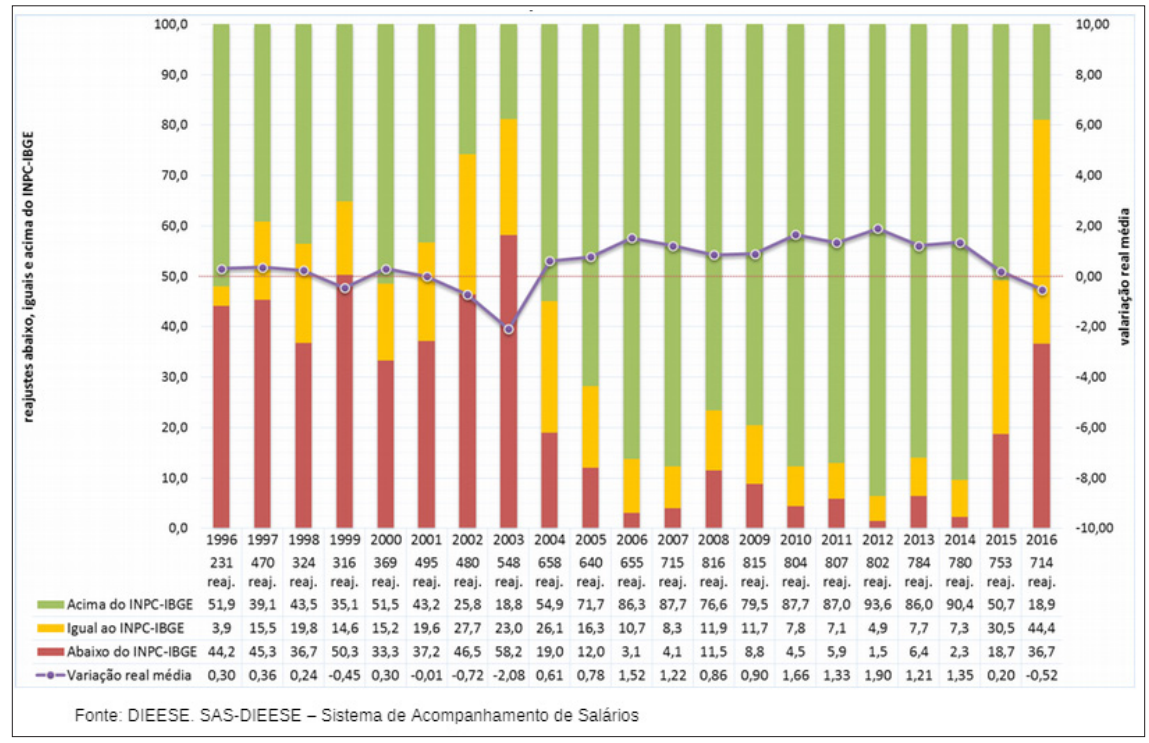

\section{LULA 2 (2007-2010): O PERÍODO DA REORGANIZAÇÃO SINDICAL}

Apesar das denúncias de corrupção e da relativa queda de popularidade de Lula, o PT consegue a reeleição em 2006, novamente superando o $\mathrm{PSDB}^{23}$. Dessa forma, na avaliação do governo, depois de ter "arrumado a casa" nos primeiros quatro anos era a hora de fazer o país crescer. Assim, em uma das primeiras medidas do segundo mandato, Lula anuncia o PAC em 28 de janeiro - programa de investimento estatal e incentivo ao investimento privado - para "quebrar os gargalos" do desenvolvimento industrial brasileiro - no seu lançamento, previa-se um investimento total de $\mathrm{R} \$ 619$ bilhões até 2010. À vista disso, o objetivo era colocar fim a diversos entraves à produção e ao escoamento dos produtos

${ }^{23}$ Partido Social Democrata Brasileiro 
e isto deveria ser feito através da construção e ampliações de usinas hidrelétricas, refinarias de petróleo, estradas, portos e aeroportos.

Além do mais, devemos nos atentar para o fato de que o lançamento do PAC é anterior à crise mundial de 2008, portanto, ocorre em um período que tanto a economia nacional crescia vigorosamente - principalmente, a partir de 2004 - e, também, em nível mundial puxado principalmente pelo crescimento da China. Contudo, com a crise de 2008, não só o PIB brasileiro se retrai (como podemos ver no gráfico abaixo) como também o mundial. Neste contexto, o PAC assume um caráter de medida anticíclica e o governo adere, desde então, a uma postura mais heterodoxa no manejo da economia.

Este programa tem impacto direto na criação de empregos, principalmente no setor da construção civil, o que está intimamente conectado com o tipo de emprego criado; como percebem Singer (2012) e Braga (2015). Logo, há nestes anos de PAC o aumento dos empregos com menor remuneração - ou seja, entre 1,01 e 2 Salários Mínimos (ver Gráfico 5). Assim, entre 1995 e 2014 percebemos um contínuo aumento dos empregos que pagam de 1,01 a 2 Salários Mínimos: eram por volta de 20\% dos empregos em 1995 e atingem mais que o dobro em 2014, 43,41\%. Em contrapartida, a faixa seguinte, de 2,01 a 5 Salários Mínimos, mantém-se equilibrada entre 35 e $40 \%$ até 2006 , quando passa a se situar por volta de $31 \%$ Destarte, os empregos que pagam mais de 5 salários mínimos decaem continuamente desde o início da série, passando de $31,53 \%$ em 1995 e se estabilizando em torno de 14\% a partir de 2009. 


\section{Gráfico 3: Produto Interno Bruto - Brasil (1994-2016) - em Bilhões de Dollares}

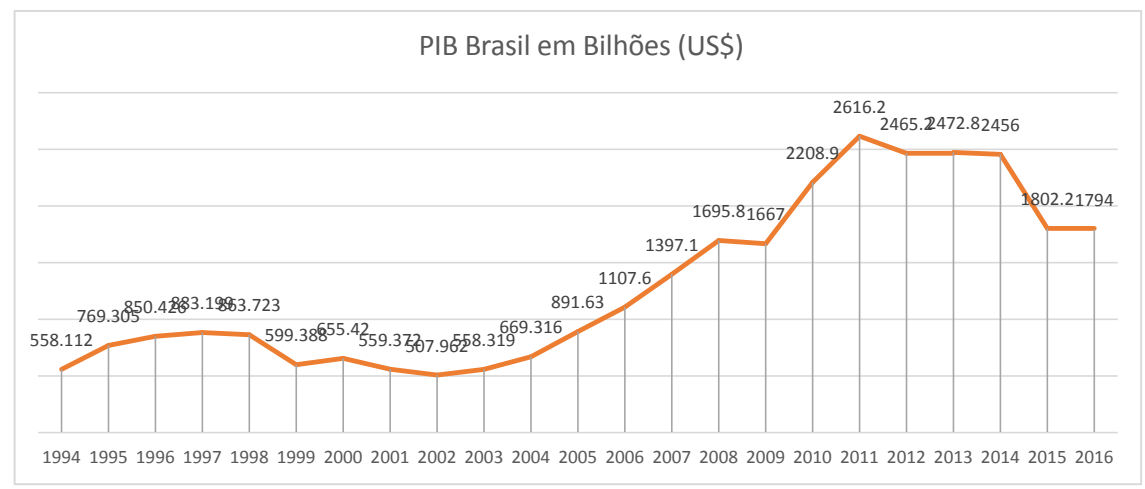

Fonte: Banco Mundial. Os valores estão na cotação do dólar americano do dia 6/7/2018. Não ajustado pela inflação.

Neste sentido, Pochmann (2012), percebe que dos empregos criados no mercado formal na década de 2000, 94\% remuneravam até 1,5 salários. Assim, para Singer (2012), ao longo dos governos do PT- principalmente a partir do PAC - uma massa considerável de trabalhadores foi libertada do "inferno do desemprego" (como atesta o gráfico 4, o desemprego caiu consideravelmente até 2014), mas também foi carregada, para o que ele chama, "precariedade com carteira assinada". Deste modo, esta precariedade pode ser percebida de várias formas: a questão salarial, a elevada taxa de rotatividade que perdura no Brasil ${ }^{24} \mathrm{e}$ os índices de acidente do trabalho que vêm aumentando ano a $a^{2} \mathrm{o}^{25}$.

\footnotetext{
${ }^{24}$ Segundo dados da RAIS e elaboração do DIEESE (2016), a geração de emprego elevada no período 2003-2014 repercutiu em estabilidade no emprego. Assim, em 2003 foram gerados 13,9 milhões de empregos, mas desses 5,2 milhões foram desligados no mesmo ano (representando $38 \%$ ). Esta proporção se mantém, com pequenas variações, até 2014 , quando se geraram 27,8 milhões de empregos, mas 11,6 milhões foram demitidos (representando 41\%).

${ }^{25}$ Segundo DIEESE (2015), em 2004 aconteceram 284.746 afastamentos por acidentes do trabalho no Brasil e, em 2014, 375.711 - representando 31\% de crescimento - enquanto a População Economicamente Ativa cresceu apenas 14\% no mesmo período no país.
} 
Gráfico 4: Índice de Desemprego Médio - Brasil (1994-2014)

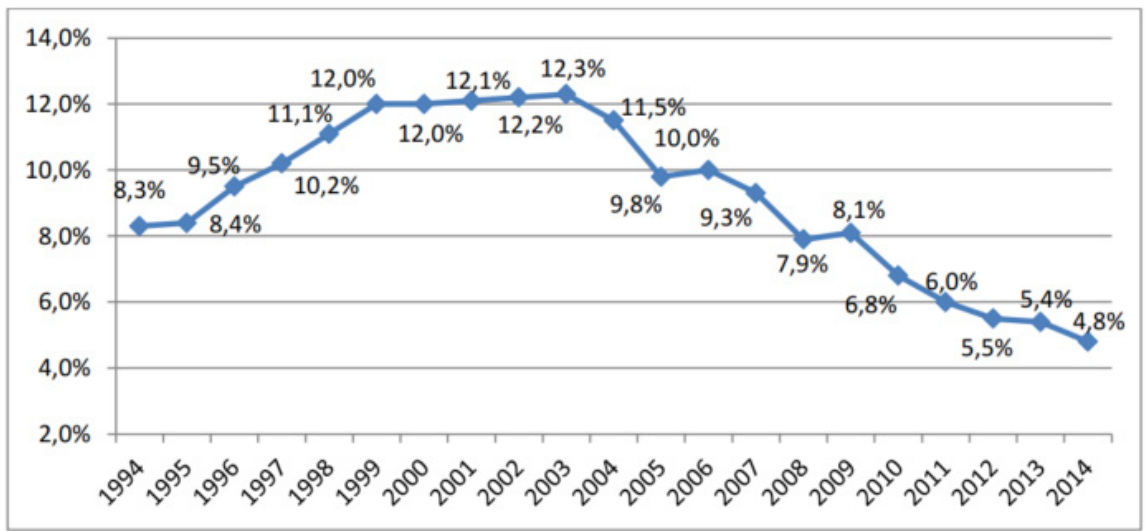

Fonte: IBGE - Pesquisa Mensal de Emprego - Acessado 3/2/2016

\section{Gráfico 5: Distribuição dos empregos criados a partir da faixa salarial}

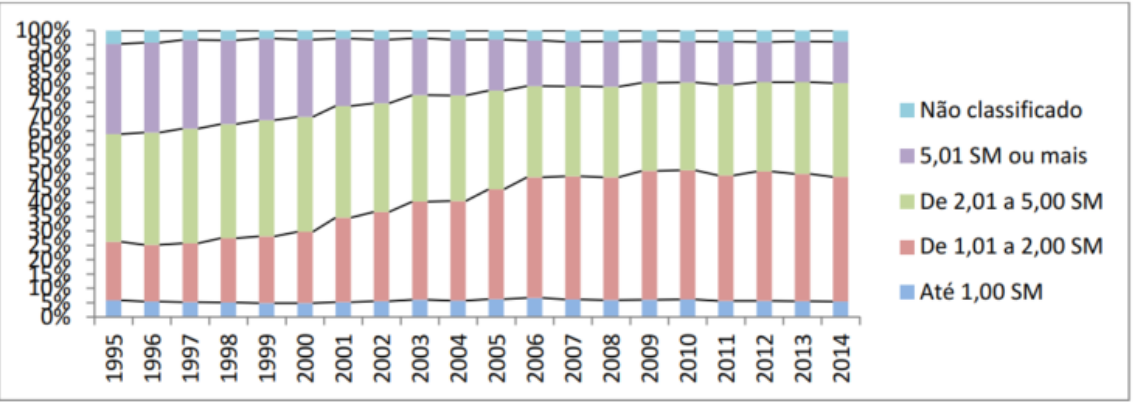

Fonte: CAGED/MTE - Elaboração própria

Pelos indicadores de greve não nos parece que os trabalhadores observaram esse cenário passivamente. Assim, corroborando com Boito e Marcelino (2010), é possível perceber o crescimento lento e gradual da ação grevista a partir de 2004 recuperando os valores referentes aos anos do segundo mandato de FHC, mas ainda distantes dos anos 80 e da 
primeira metade dos 90. O salto qualitativo nos indicadores se dá em 2012, como abordaremos a seguir. No entanto, parece uma hipótese explicativa interessante a ideia de que os trabalhadores fazem mais greves, pois percebem o momento favorável no mercado de trabalho aquecido, mas também percebem que existe a continuidade - ou até aprofundamento das relações de trabalho precárias anteriores. Deste modo, fazem greves por melhores condições de trabalho e salário e pela ampliação de direitos - essas são as "greves ofensivas" e, como percebe Marcelino (2017), há um crescimento e prevalência desse tipo de greve até 2012.

\section{Gráfico 7: Greves - Brasil (1984-2013) ${ }^{26}$}

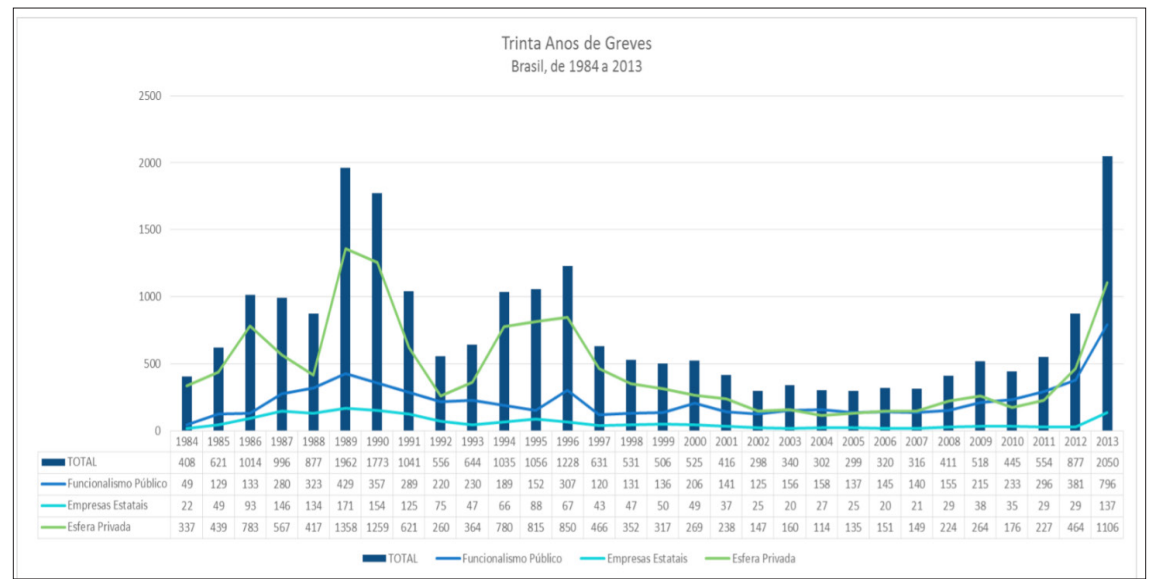

Elaboração DIEESE (2015)

${ }^{26}$ O DIEESE (Departamento Intersindical de Estaística e Estudos Socioeconômicos) já possui os indicadores de greve dos anos de 2016 e 2017: 2093 e 1566 greves, respectivamente. Porém, como não possui os valores para 2014 e 2015 - anos fundamentais para nossa análise do segundo governo Dilma - optamos por encerrar o gráfico em 2013. 


\section{Gráfico 6: Tipos de Reivindicações Presentes nas Greves - 2004-2013}

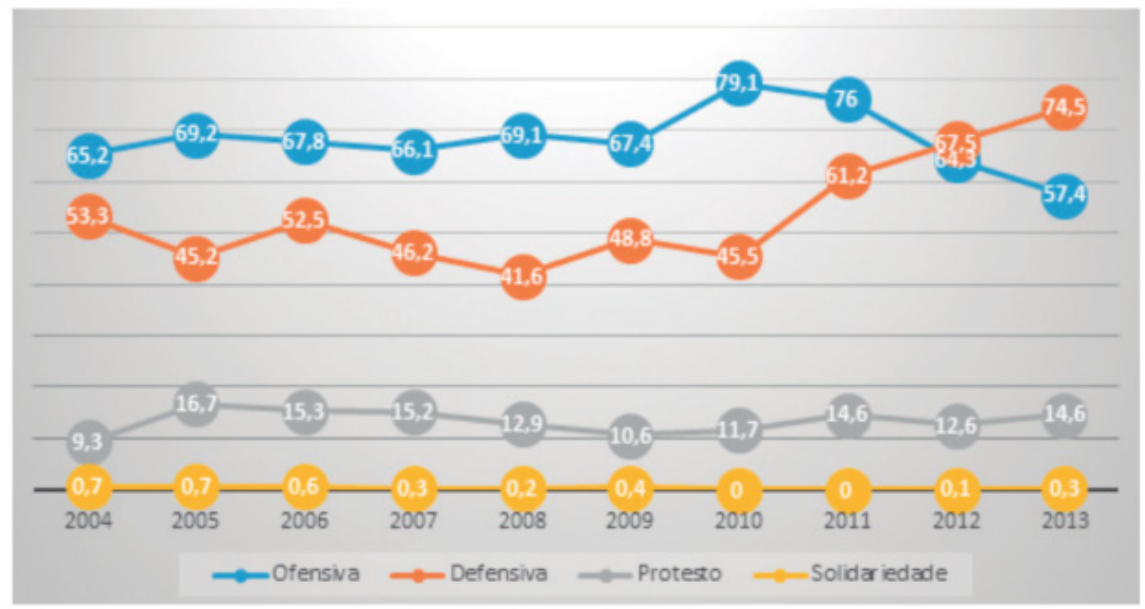

Obs:: Cada greve pode conter mais de um tipo de reivindicação. Assim, a soma das colunas de cada ano não corresponde ao número total de greves, nem a soma das porcentagens será igual a $100 \%$.

Fonte: Dieese (2015, 2012, 2007 e 2006). Elaboraçảo de Danilo Torini.

\section{LEI DAS CENTRAIS SINDICAIS}

A aprovação da Lei das Centrais Sindicais (Lei 11.648/08) reconhece as centrais e estabelece as suas funções:

coordenar a representação dos trabalhadores por meio das organizações a ela filiadas e participar de negociações em fóruns, colegiados de órgãos públicos e demais espaços de diálogo social que possuam composição tripartite, nos quais estejam em discussão assuntos de interesse geral dos trabalhadores (BRASIL, 2008).

Contudo, não estabelece a possibilidade de as centrais negociarem o salário mínimo, ainda que permita a participação delas nas negociações nacionais por categorias. Isto é algo que limita a atuação das mesmas em um país como o Brasil no qual a maioria das movimentações sindicais decorrem dos reajustes salariais.

Temáticas, Campinas, 27, (53): 185-224, fev./jun. 2019 
Logo, esta mudança provoca uma reorganização das cúpulas das centrais com a criação de duas centrais sindicais: CTB e a UGT. A primeira delas, Central dos Trabalhadores e Trabalhadoras do Brasil é uma cisão da CUT a partir da corrente interna Corrente Sindical Classista (CSC) ligada ao $\mathrm{PCdoB}^{27}$. Essa corrente tem um percurso interessante: na década de 1980 não participa do "novo sindicalismo" e não participa da criação da CUT, mas com a aproximação ao PT nas eleições de 1989, as diferenças ideológicas e práticas parecem diminuir e a CSC entra na CUT em 1990 na qual permanece até 2006 quando rompe com ela no $9^{\circ}$ Congresso Nacional da CUT.

Entretanto, isto não significa considerar a central originária como adversária, tampouco torna-la oposição ao governo Lula. Ainda que exista diferenças em relação à CUT - divergem sobre a Convenção 87 da OIT que versa sobre a unicidade sindical e possuem uma avaliação de que a CUT não representava mais a diversidade do movimento sindical -, a cisão ocorreu de maneira bem amigável. Dessa forma, diversos pesquisadores, como Galvão et al (2015), compreendem que esta ruptura tem a ver mais com a percepção de que aprovada a Lei das Centrais Sindicais, a corrente poderia ter acesso ao fundo do Imposto Sindical destinado às centrais sozinha. Assim,

trata-se da possibilidade de utilizaros recursos da contribuição sindical para constituir uma estrutura alternativa de poder, já que seus próprios dirigentes alegam que, a despeito das divergências, não se trata de romper com a CUT, nem de considerá-la adversária (GALVÃO et al, 2015, p. 192) ${ }^{28}$.

A CTB é fundada em 2007 e já em 2008 atinge as cláusulas de reconhecimento do Ministério do Trabalho e Emprego sendo reconhecida como central sindical oficial. Também a partir da efetivação da Lei 11.648/08, em 2007 funda-se a UGT através da fusão de três grupos/ centrais sindicais que sozinhos não atingiriam as cláusulas: CAT, SDS e

\footnotetext{
${ }^{27}$ Partido Comunista do Brasil.

${ }^{28}$ Cf. entrevista de João Batista Lemos a Lobregatte (2007).
} 
CGT $^{29}$. A CAT era formada por grupos ligados ao sindicalismo cristão, já a SDS é um resultado de um processo de cisão da FS ligada ao PSDB e a CGT é oriunda do grupo de Antônio Rogério Magri e reúne diversas federações.

À primeira vista, a criação da UGT pode ser explicada apenas por um viés pragmático: atingir os critérios estabelecidos pela Lei das Centrais; o que não deixa de ser verdade. Mas a aproximação dessas correntes sindicais não acontece de forma aleatória, são todas elas representantes do setor mais conservador do sindicalismo brasileiro, aqueles descendentes do "velho" sindicalismo - em oposição ao "novo sindicalismo" que daria origem à CUT. Por isso, com a aproximação da FS - antigo guarda-chuva dos setores menos combativos do sindicalismo brasileiro - com a CUT, esses setores podem ter sentido a necessidade de se organizarem também nas cúpulas sindicais.

Portanto, a UGT surge como uma central que defende "a 'modernização' das práticas sindicais a partir da incorporação de mecanismos gerenciais típicos da administração das empresas capitalistas das últimas décadas" e de um "sindicalismo cidadão, ético e inovador" (LEMOS, 2014). Algo muito próximo do que defendeu a FS na década de $1990^{30}$.

\section{CONCLAT}

Em 2006 inicia-se, a partir da Frente de Esquerda e Socialista conformada pelo PSOL e PSTU para a presidência da República, a discussão sobre a fusão das centrais sindicais majoritariamente impulsionada pelos

\footnotetext{
${ }^{29}$ Em 1989, no seu II Congresso, a CGT havia se dividido entre a CGT Central, ligada a Joaquinzão, PCB e MR8, e a CGT Confederação de Magri e Medeiros. A primeira acrescenta o "do Brasil" em seu nome e torna-se CGTB em 2004, ligada ao MR8 - que posteriormente torna-se o Partido Pátria Livre. Em 2008, a CGTB atinge os critérios do MTE, perdendo em 2011. Já a CGT - Confederação - divide-se quando Medeiros irá fundar a Força Sindical e outros setores buscam conformar-se enquanto confederação para ter acesso aos recursos do Imposto Sindical, já garantidos pela lei para as federações e confederações. É este grupo "CGT-Confederação" que forma a UGT.

${ }^{30}$ Para maiores informações sobre a UGT, cf. LEMOS (2014).
} 
dois partidos, Conlutas e Intersindical. Este processo não pode ser completamente dissociado da Lei das Centrais Sindicais, mas a nosso ver, obedece a outra ordem; tanto é que o resultado não é a fusão. Apesar do avançar das discussões, ao atingir o CONCLAT em 2010 na cidade de Santos (SP), as diferenças se sobrepõem e a unificação não ocorre.

Ademais, a Intersindical é resultado dos grupos que atuavam na CUT compostos por setores do PSOL, PCB e Alternativa Sindical Socialista (ASS). Em seu processo de fundação as organizações possuíam acordo de que ainda seria necessário um processo maior de ruptura com a CUT para a conformação de uma nova central sindical. Por isso, naquele momento entendem que seria possível permanecer tanto na CUT como fora dela e que este processo deveria servir para organizar aqueles que buscassem uma ação sindical "democrática, plural, autônoma, socialista e baseada na independência de classe" (GALVÃO et al, 2015, p.110). Contudo, a criação da Conlutas evidencia as diferentes leituras existentes a respeito: para os grupos ligados ao PSOL, é possível a conformação de uma nova central conjuntamente com o PSTU; já para ASS e PCB isso não ocorre e deve se permanecer enquanto um projeto. Deste modo, em 2008, no II Encontro Nacional da Intersindical, existe a primeira ruptura, quando passam a existir dois grupos que reivindicam o nome Intersindical: 1) Intersindical - instrumento de luta e organização da classe trabalhadora (ligado à ASS e contrário à criação de uma central); e, 2) Intersindical - instrumento de luta, unidade de classe e construção de uma nova central - ligado ao PSOL e que queria discutir com a Conlutas o processo de formação de uma central sindical.

Assim, o primeiro grupo não participa do CONCLAT de 2010 e segue organizando-se paralelamente às centrais sindicais, sem pedir o reconhecimento ao MTE; a principal referência desta organização é o Sindicato dos Metalúrgicos de Campinas e Região. Já a Intersindical "prócentral" realiza o III Encontro Nacional e prepara-se para o CONCLAT. Em Santos, a fusão não acontece, alegadamente por divergências quanto ao nome da futura central. Havia três propostas: as duas centrais originárias pretendiam manter seus nomes e o ANDES e o Movimento dos Trabalhadores Sem Teto (MTST) propõem Central Sindical e Popular 
(CSP). Logo, em uma tentativa de consenso, propõe-se "CSP-ConlutasIntersindical", mas nesse momento os delegados oriundos da Intersindical não participam da votação e rompem com o congresso. Desse modo, é aprovado o nome "CSP-Conlutas".

$\mathrm{Na}$ verdade, as diferenças de fundo eram outras. O setor que vai compor a CSP-Conlutas defendia o caráter de central sindical e popular nos moldes da Central Operária Boliviana e isso incluía a participação de movimentos sociais, como o MTST, estudantis e de luta contra opressões. Porém, os setores que compunham a Intersindical se opunham à participação desses movimentos e à proposta de paridade de voto e recursos dentro da central. Mas esse segundo setor perde a votação e a votação seguinte era sobre o nome, quando ocorre a ruptura formal. ${ }^{31}$

Assim, temos mais duas centrais sindicais. Uma delas é a CSPConlutas descendente direta da Conlutas, acrescida de setores do PSOL, MTST e ANDES. A central possui seu caráter sindical e popular até hoje, mesmo após a ruptura do MTST com a central por divergências organizativas em 2012. A central se unifica em torno daqueles que discordam do apoio da CUT aos governos do PT e da participação em organismos tripartites. Como já dissemos, a central é oriunda dos críticos à Reforma da Previdência, o que ajuda a entender sua composição majoritariamente de funcionários públicos (GALVÃO et al, 2012). Muitos autores classificam a central como sendo majoritariamente ligada ao PSTU, mas, embora esse partido exerça força hegemônica dentro da central, ela reúne outras correntes trotskistas, ligadas ou não ao $\mathrm{PSOL}^{32}$. Chama atenção o fato da CSP-Conlutas se colocar contrária ao Imposto Sindical e à unicidade sindical e possuir uma avaliação negativa da Lei das Centrais, mas ao mesmo tempo pedir o reconhecimento como central sindical oficial junto ao MTE desde sua criação.

\footnotetext{
${ }^{31}$ Cabe-nos notar a interessante posição do PCB ao liberar seus militantes a participar dos congressos e instâncias das centrais sindicais que seus sindicatos são filiados, através do agrupamento Unidade Classista.

${ }^{32}$ Como o MES (Movimento Esquerda Socialista), CST (Corrente Socialista dos Trabalhadores), Resistência, LSR (Liberdade, Socialismo e Revolução), todas estas ligadas ao PSOL; além do MRT (Movimento Revolucionário de Trabalhadores).
} 
Já a Intersindical anuncia em seu manifesto de fundação o objetivo de retomar os marcos e o norte da CUT na década de 1980. Com o insucesso do CONCLAT, a Intersindical "pró-central" mantém-se como uma organização formada majoritariamente por correntes do PSOL e dirigida pelo campo que também dirige o partido, "Unidade Socialista". Desde 2010, a Intersindical inicia o processo de transformação em central sindical, o que se efetiva em 2014 - mas segue até hoje sem o reconhecimento do MTE. Entre os principais sindicatos filiados à central, encontra-se o Sindicatos dos Químicos Unificados - Campinas e Osasco ${ }^{33}$.

\section{DILMA (2011-2016): DA NOVA MATRIZ ECONÔMICA AO GOLPE JURÍDICO PARLAMENTAR}

Com a eleição de Dilma Rousseff, há um realinhamento do modelo de gestão econômica dos governos petistas. Através da "Nova Matriz Econômica" (NME), buscava-se restringir o rentismo e favorecer o investimento produtivo ${ }^{34}$ ao mesmo tempo que foram aplicadas medidas austeras para preparar a economia para o crescimento futuro. Entretanto, o crescimento esperado não acontece a contento e com o decorrer do primeiro mandato de Dilma a economia desacelera, configurando num primeiro momento um cenário de estagnação (2011-2013) seguido por recessão (a partir de 2014), como podemos observar anteriormente no gráfico 2 .

Dessa forma, Bastos (2017) aponta três motivos para a desaceleração da economia: 1) o fim do ciclo de ampliação do consumo e do crédito do mercado interno devido ao endividamento das famílias e à redução da demanda por produtos de maior valor agregado; 2) a incapacidade da desvalorização cambial conter a queda dos valores da exportação,

\footnotetext{
${ }^{33}$ Para maiores informações sobre as novas centrais sindicais, conferir Galvão et al (2015) trabalho que retoma o histórico das centrais e traça as bases sociais dessas novas entidades.

${ }^{34}$ Essa política econômica ficou conhecida como Nova Matriz Econômica (NME), foi implementada a partir do primeiro mandato de Dilma e definida por BASTOS (2017) a partir das seguintes medidas: "redução das taxas de juros e tarifas de energia elétrica; desonerações tributárias e crédito subsidiado; desvalorização cambial e protecionismo industrial seletivo; concessões de serviços públicos para a iniciativa privada".
} 
devida, principalmente, à queda dos preços das commodities no mercado internacional; 3) a queda dos investimentos na construção civil. Ademais, esta queda se deve, de um lado, à reversão do ciclo de investimento familiar para aquisição e construção residencial e, de outro, ao fato de que as principais concessões de obras no setor energético e de infraestrutura já haviam sido realizadas no final do mandato de Lula e primeiros anos de Dilma, e as novas concessões no setor de logística não avançaram até 2014, devido à espera do capital pelo resultado da eleição presidencial do final daquele ano.

Neste cenário, há uma diminuição da rentabilidade do capital. Ainda segundo Bastos, as taxas de lucro diminuem devido à elevação de custos não vinculados à produção ${ }^{35}$. Para recuperar sua rentabilidade, o capital busca aumentar a extração de mais-valia através da diminuição relativa do valor pago ao trabalho e da tributação. Contudo, concomitantemente, as "Jornadas de Junho" e a ação sindical, explicitada no salto de greves a partir de 2012 expressam as exigências populares por mais investimento em áreas sociais e melhor remuneração do trabalho - ou seja, no sentido inverso das demandas do capital.

Com o aprofundamento da crise econômica em 2014, setores do capital financeiro iniciam um movimento para pressionar pela relocalização do governo na atuação econômica. Como expresso por Volpon (2014), era preciso aplicar o "pragmatismo sob coação", isto é, a austeridade dura e crua. Assim, após a sua reeleição, Dilma reorganiza seu governo de maneira a retomar uma matriz econômica favorável ao capital financeiro - tanto é que o próprio Volpon é nomeado para a diretoria de Assuntos Internacionais do BC e Joaquim Levy, até então economista-chefe do Bradesco, torna-se Ministro da Fazenda.

Fazemos esta recuperação da gestão econômica dos governos Dilma para perceber que, na verdade, existe uma profunda oscilação entre as matrizes econômicas - da ortodoxia à heterodoxia, voltando para ortodoxia - em poucos anos; e é exatamente essa oscilação que, ao nosso ver, desestabiliza o governo Dilma.

\footnotetext{
${ }^{35}$ Como aluguéis e rubricas em parte afetadas pelo encarecimento do dólar e produtos para revenda, fretes, seguros, leasing, royalties e passivo financeiro.
} 
Para compreendermos este processo, antes devemos perceber que os governos petistas se baseiam em um difícil equilíbrio entre frações de classe e classes distintas: o capital financeiro, o produtivo e a classe trabalhadora. Portanto, quando o primeiro mandato de Dilma aplicou a NME favoreceu mais o capital produtivo, desagradando o setor rentista e criando as primeiras fissuras com o capital financeiro - essa fração capital vê sua centralidade diminuída ao ter seus lucros reduzidos com a baixa das taxas de juros e desvalorização do câmbio, provocando a redução do custo fiscal da dívida pública para o país.

Além disso, no início da aplicação da NME, foram realizadas medidas de austeridade que despertaram o descontentamento das bases populares do governo. Com o insucesso do rearranjo econômico, a crise econômica se aprofundou, levando o governo Dilma à adoção do ajuste fiscal, o que provocou um clima de "estelionato eleitoral" 36 na população altamente promovido pelos grandes meios de comunicação, já que enquanto candidata a presidente havia prometido que não seguiria por esse caminho. Assim, isso contribuiu para o afastamento da classe trabalhadora da base do governo.

Com este cenário econômico de pano de fundo, os movimentos sociais - incluso o sindicalismo - passaram longe da letargia nos anos Dilma. Quando poucos analistas esperavam, o salto para 877 greves em 2012 devia ter sido o primeiro sinal de alerta para governos e cientistas sociais de que havia uma efervescência na classe trabalhadora. Afinal, greves importantes aconteceram neste ano, principalmente por fora da estrutura sindical e nas obras do PAC (cf. CAMPOS, 2016), mas também greves nacionais de categorias "tradicionais", como dos docentes universitários e bancários.

Então sobreveio 2013, o ano que não acabou. As grandes capitais são marcadas por protestos juvenis contra o aumento da passagem, desde janeiro em Porto Alegre. Porém, quando o Movimento Passe Livre coloca,

\footnotetext{
${ }^{36}$ Alguns autores e atores políticas recorrem a esse termo para designar a diferença entre as promessas de campanha e o "entregue" após a ascensão ao poder. No caso do segundo mandato de Dilma, autores como Domingues (2015) e Pimentel (2015) o utilizam para retratar essa discrepância.
} 
junto com outros movimentos de esquerda, 20 mil pessoas em São Paulo e é duramente reprimido pela Polícia Militar, a situação se modifica. $\mathrm{Na}$ semana seguinte, 2 milhões de pessoas foram às ruas pelo país e não foi "apenas por 20 centavos"37, mas por educação, saúde, transporte público, segurança nos "padrões FIFA"38, além de uma infinidade de outras reivindicações.

Foge de nosso escopo compreender as "Jornadas de Junho", mas esta tem reverberações no movimento sindical, ao nosso ver duas são principais: 1) a explosão de greves, se já crescia a ação grevista no ano anterior, em 2013 atinge 2050 greves - recuperando os marcadores da década de $1980^{39}$; 2) as centrais sindicais - de todos os matizes políticos convocam em sequência dois dias nacionais de paralisação e/ou luta: 11 de julho e 30 de agosto.

Ainda que no primeiro dia, com forte influência dos "ventos de junho", 3 milhões de trabalhadores tenham realizado greve (BRAGA, 2015), é possível afirmar, sem grandes dúvidas, que o movimento sindical e os partidos de esquerda passaram longe de "Junho" (MATTOS, 2014). Tanto foram rechaçados por "populares" e militantes de extrema-direita que gritavam "Fora Partido/PT" para toda bandeira e faixa de partidos, mesmo do PSOL e PSTU; como também não souberam dialogar com as inquietações que vinham das ruas, principalmente, na questão da segurança e da corrupção.

Desse modo, Marcelino (2017), ao tentar demonstrar o momento favorável do sindicalismo nos governos petistas, utiliza como elemento explicativo o fato de que os governos do PT foram os únicos que não passaram por, no mínimo, uma greve geral contra sua política econômica. Apesar desse fator, o descontentamento que explodiu em junho de 2013 indica a possibilidade de construção de uma greve geral no país que

\footnotetext{
${ }^{37}$ Palavra de ordem que se massificou pelo país aludindo ao valor do aumento da passagem em São Paulo.

${ }^{38}$ Em alusão aos estádios e demais obras da Copa do Mundo FIFA 2014 que se aproximava.

39 Mattos (2016) faz referência a um "efeito bumerangue" entre as "Jornadas de Junho" e as greves posteriores. Como observa Mendonça (2017), não há uma relação direta causal, mas há referências nos discursos, na estética e no trabalho de base em níveis diferentes a partir dos perfis políticos ideológicos dos sindicatos.
} 
pudesse exigir do governo a adoção de uma perspectiva mais heterodoxa e voltada para investimentos sociais. Todavia, as centrais sindicais aliadas ao governo ${ }^{40}$, que representavam a maioria esmagadora dos trabalhadores sindicalmente organizados, construíram com muito menos afinco as mobilizações de 2013 do que nos governos antecessores e posteriores.

Assim, os analistas têm fornecido algumas explicações para o novo ciclo grevista aberto em 2012. Nos concentraremos em três delas:

(1) Braga (2015) vê que os anos de governo do PT geraram um crescimento econômico apoiado na criação de empregos precários e mal remunerados, além da permanência do regime despótico na maioria desses novos postos de trabalho. Assim, quando os primeiros limites do modelo petista de desenvolvimento são explicitados, a classe trabalhadora se vê obrigada a fazer greves.

(2) Já Linhares (2015) acredita que a realização da Copa do Mundo no Brasil, com o grande investimento de capital público e privado, aumentou o poder de barganha tanto das categorias mais mobilizadas quanto das menos, fazendo com que todos, praticamente, fizessem greves entre 20122014. Isto explicaria inclusive a reversão da tendência de mais greves ofensivas a partir de 2013, afinal, categorias pouco mobilizadas, com poucos direitos consolidados como comerciários, telemarketing, construção civil - viram a possibilidade de garanti-los.

(3) Essa tese é corroborada por Marcelino (2017), mas a autora considera que o crescimento de greves está conectado ao momento favorável ao sindicalismo aberto a partir da eleição de Lula. Ou seja, os governos petistas permitiram que os atores sindicais e trabalhadores percebessem maiores possibilidade de conquistar suas reivindicações. Para se contrapor à tese de que as lideranças sindicais haviam

\footnotetext{
${ }^{40}$ Como percebe Galvão (2012), CUT, FS, CGTB, CTB, NCST, UGT e CSB fizeram parte da base de apoio dos governos do PT.
} 
sido cooptadas, Marcelino afirma que os setores que mais fizeram greves foram também aqueles que mais tiveram lideranças ocupando cargos de segundo e terceiro escalão do governo federal e que também são as principais bases da CUT: metalúrgicos, bancários e educação. Isto é, a ocupação das lideranças em instâncias estatais não intimidou a luta reivindicativa das bases.

Um elemento importante para percebermos o momento - mais ou menos favorável - do sindicalismo é a distribuição dos reajustes salariais comparando com a inflação do período. Como podemos observar no Gráfico 2, desde $2004^{41}$ o Brasil registra um aumento dos acordos acima do INPC-IBGE, culminando em 2012 quando 93,6\% dos acordos foram superiores à inflação. Contudo, em 2013 esse número oscila para baixo (86\%) - daí a explicação de Linhares (2015) sobre os setores tradicionalmente menos mobilizados - no ano seguinte, oscila para cima de novo, com 90,4\% de acordos com ganhos reais de salário. No entanto, é a partir de 2015 que o cenário se deteriora de vez, atingindo apenas 18,9\% dos acordos coletivos com reajuste acima do INPC-IBGE.

Dessa forma, acreditamos que as três teses ajudam a compor o complexo quadro explicativo para o boom de greves no biênio 2012-2013 ${ }^{42}$. Mas há outros elementos fundamentais para compreensão do quadro: 1) o crescimento econômico com criação de empregos desde 2004 até 2012; 2) a ausência de melhora qualitativa no mercado de trabalho; em alguns aspectos, há deterioração, como na questão da terceirização; 3) desde 2011, setores pouco ou nada mobilizados passam a realizar ações grevistas, impulsionado novos e velhos atores sindicais a também se mobilizar; 4) em 2012, a economia já dá os primeiros sinais dos limites do modelo de desenvolvimento petista; 5) a melhoria do diálogo entre governo e trabalhadores desde a chegada de Lula à presidência. Em suma, temos um mercado de trabalho precário e mal remunerado, mas aquecido com

\footnotetext{
${ }^{41}$ Com exceção de 2008 e 2009, anos de maior impacto da crise econômica mundial.

${ }^{42}$ Como percebe Linhares (2015), esse grande número de greves também se repete em 2014, mas os dados do DIEESE ainda não estão consolidados, portanto, ficamos nas "impressões".
} 
oportunidades de conquistas econômicas para os trabalhadores, parecenos que é por isso que estes lançam-se a fazer greves - como citamos anteriormente, elaboram Pochmann (2012) e Braga (2015).

\section{AS MANIFESTAÇÕES DOS “VERDE-AMARELO” E O GOLPE DE 2016}

Desde os resultados extremamente apertados das eleições de 2014, iniciaram-se manifestações pedindo o impeachment de Dilma e até mesmo "intervenção militar" convocadas por partidos de oposição e de direita, como PSDB e Democratas, que contaram com a participação de novos movimentos sociais de direita, como Movimento Brasil Livre, "Vem pra Rua" e outros, mas também teve a participação de sindicatos ligados à CGTB e FS ${ }^{43}$ - tendo Paulinho da Força, deputado federal e principal figura dessa central, participado ativamente das manifestações. Esta central já havia rompido com o governo Dilma e apoiado Aécio Neves, candidato derrotado pelo PSDB.

Em 13 de março de 2015, PT, PCdoB, CUT e CTB realizam as primeiras manifestações em apoio ao governo Dilma e contra o golpe. Porém, muito aquém das manifestações que ocorreriam dois dias depois com milhares de "verde-amarelo" por diversas capitais do país. Desse modo, o ano de 2015 é marcado por manifestações de ambos os lados, até quando em dezembro, Eduardo Cunha, como presidente da Câmara, aceita o pedido de afastamento da presidente pelas "pedaladas fiscais". Assim, as demais centrais sindicais se veem obrigadas a se posicionarem a partir de então: ainda em dezembro de 2015, a NCST posiciona-se contra o impeachement $t^{14}$, contudo sem chamar de "golpe", a IntersindicalCentral se posiciona contraria ao impeachment, percebendo-o como golpe ${ }^{45}$, já Intersindical-Instrumento entendia que essa não era uma questão que

\footnotetext{
${ }^{43}$ É importante frisar que dentro da FS existem sindicatos e sindicalistas que se aproveitaram do posicionamento "neutro" da central para declarar-se contra o afastamento de Dilma, como é o caso de Juruna, Secretário-Geral da central, e os Sindicatos dos Metalúrgicos de Santo André (SP) e Curitiba (PR). Fonte: https://goo.gl/Zakjf8 - Acessado 16/1/19.

${ }^{44}$ Fonte: https://goo.gl/rk4uRw - Acessado 16/1/19.

${ }^{45}$ Fonte: https://goo.gl/zSWrnq - Acessado 16/1/19.
} 
cabia aos trabalhadores, algo muito parecido com o posicionamento da CSP-Conlutas, mas esta afirmava que o impeachment não era suficiente, "nem Dilma, nem Aécio", adotando posteriormente o lema "Fora todos eles" "46. No outro campo, tem-se adesão da $\mathrm{UGT}^{47}$ e CSB a favor do impeachment e participando dos atos.

Apesar do posicionamento das centrais sindicais, é possível afirmar que as manifestações pró e contra impeachment passaram ao largo dos sindicatos, não existindo movimentações de trabalhadores para participar dos atos pelas entidades sindicais. Mesmo CUT e CTB possuíram dificuldades de movimentar suas bases para se posicionar contrariamente ao golpe, não existindo qualquer greve ou paralisação de trabalhadores para participação nas manifestações, nem nos dias de votação no Congresso Nacional.

Se os sindicatos e centrais sindicais não conseguiram ser agentes determinantes na luta contra o golpe, ao nosso ver, encontram-se dois motivos: o processo de afastamento das bases e a institucionalização do sindicalismo nas décadas de 1990 e 2000. Além da queda brusca da aprovação de Dilma na classe trabalhadora, desde junho de 2013, mas, principalmente, o sentimento de "estelionato eleitoral" amplamente difundido após 2014.

Ocorre a criação de duas frentes de partidos e movimentos sociais na luta contra o golpe jurídico-parlamentar: a "Frente Brasil Popular" (FBP), composta por PT, PCdoB, $\mathrm{PCO}^{48}, \mathrm{MST}^{49}, \mathrm{UNE}^{50}$, CUT e CTB, além de outros movimentos sociais desse espectro político; também foi criada a "Frente Povo Sem Medo"(FPSM), capitaneada pelo MTST, PSOL e PCB e que a Intersindical-Central compõe conjuntamente com outros movimentos sociais. Estas frentes ganharam visibilidade e foram as responsáveis pelo movimento da maior parte dos ativistas para os atos e manifestações contra o golpe.

\footnotetext{
${ }^{46}$ Fonte: https://goo.gl/rPnaDn - Acessado 16/1/19.

${ }^{47}$ Fonte: https://goo.gl/p7gVZr - Acessado 16/1/19.

${ }^{48}$ Partido da Causa Operária.

${ }^{49}$ Movimento de Trabalhadores Sem Terra.

${ }^{50}$ União Nacional do Estudantes.
} 


\section{CONCLUSÃO}

Isso posto, Boito (2018) e outros autores sustentam a tese de que os governos petistas compuseram uma "frente neodesenvolvimentista" (BOITO, 2018, entre outros). Logo, desta retomaria algo fundamental para podermos traçar um balanço final sobre a interação entre o sindicalismo brasileiro e os governos Lula e Dilma: estes baseiam-se em um difícil equilíbrio entre frações de classe e classes distintas - o capital financeiro, o produtivo e a classe trabalhadora. Dentro desta frente podemos perceber que o movimento sindical é como um "sócio menor" da repartição das conquistas destes treze anos. Se isso foi importante do ponto de vista de legitimação e apoio popular, foi constantemente preterido em favor do grande capital e até mesmo dos setores mais pauperizados e não organizados em sindicatos (SINGER, 2012 e DRUCK, FILGUEIRAS, 2007).

Mas, sem embargo, a maioria das centrais sindicais compuseram essa frente, apoiando os governos e as candidaturas - Lula 2006 e Dilma 2010, é apenas em 2014 que alguns setores começam a retirar-se da base de apoio, como a FS. Dentre as centrais trabalhadas neste artigo, apenas a CSP-Conlutas e as duas Intersindicais se colocaram em oposição contínua nesses 13 anos; com a importante ressalva de que a Intersindical-Central se posicionou categoricamente contra o impeachment, mesmo sem aderir ao governo.

$\mathrm{Na}$ lógica desse tênue equilíbrio entre classes e frações de classe, há um difícil jogo político de buscar agradar a todos na divisão do bolo - para utilizar uma expressão de Lula. A bem da verdade, sem surpresas, é que a classe trabalhadora fica com a menor parte dessa divisão. Mas de certa maneira esse equilíbrio é mantido de forma satisfatória nos mandatos de Lula e primeiros anos de Dilma; no entanto, com o aprofundamento da crise econômica, a balança pende e o fiel é defenestrado, levando consigo a própria classe trabalhadora.

Para finalizar, abordo quatro posicionamentos distintos realizados pelas centrais a fim de perceber quais foram as respostas dadas por elas à questão trazida no início desse artigo: o que fazer frente a um governo 
advindo do próprio sindicalismo? 1) A CUT, central que dá origem a Lula e às principais lideranças do PT, apesar de perceber limitações dos governos Lula e Dilma, destaca um avanço à abertura de diálogo e às conquistas qualitativas da classe trabalhadora, como a valorização do trabalho e os direitos garantidos no período. 2) A Força Sindical, outrora antítese e adversária da CUT, aproxima-se desta ao longo da década de 1990 e do PT por, praticamente, 10 anos seguidos; afastando-se e fazendo oposição aos governos petistas apenas a partir de 2014. 3) Uma das principais mudanças no campo sindical promovidas diretamente pelo governo petista foi a Lei das Centrais Sindicais, através dela temos a reorganização e a criação de duas centrais: CTB - resultado da cisão da CSC da CUT - e a UGT oriunda da fusão de SDS, CGT e CAT; de matizes políticas distintas, o surgimento de ambas centrais é altamente pragmático, contudo fazem parte da sustentação sindical dos governos Lula e Dilma, a CTB até o fim e a UGT até 2014. 4) Na extrema-esquerda do sindicalismo brasileiro, tem-se um movimento contraditório, primeiro de ruptura de grupos (FES, ASS e MTS) com a CUT por diferenças políticas e avaliações distintas sobre o governo Lula, depois, as centrais que dali surgem, Conlutas e Intersindical, fracassam em sua tentativa de fusão, vindo a constituir três entidades sindicais distintas.

Os dois últimos pontos levaram muitos analistas a iniciarem discussões acerca da possibilidade de estar acontecendo no Brasil um processo de reorganização e/ou revitalização sindical (GALVÃO, 2014a), principalmente, quando observamos a experiência da CSP-Conlutas, como central sindical e popular, somando-se às diversas greves ocorridas entre 2011 e 2015 à revelia das direções dos sindicatos. Essa revitalização poderia ensejar uma comparação entre a realidade brasileira e movimentos internacionais de aproximação entre sindicalismo e movimentos sociais (GALVÃO, 2014b). No entanto, à luz do tempo, é possível perceber que não há um processo de revitalização da ação sindical e a reorganização se dá nas cúpulas das entidades, sem significar um movimento mais profundo e desde as bases dos sindicatos.

Ao fim desse balanço, consideramos que ocorreu no movimento sindical brasileiro um processo de institucionalização, no sentido de 
ampliação do reconhecimento, interação e participação no e com o Estado, principalmente durante os governos petistas. À época esta situação foi entendida por atores e analistas como uma virtude e maturidade do sindicalismo brasileiro. Contudo, como resultante da reestruturação produtiva e neoliberalismo também ocorreu o arrefecimento das ações diretas e, principalmente, grevistas - isto sé dá conjuntamente ao processo de distanciamento das bases.

Parece-nos que, ao fim e cabo desses 13 anos de governo petista, nas relações de trabalho e sindicais o resultado foi altamente custoso prova disso é a incapacidade do sindicalismo resistir à agenda neoliberal do grande capital para o país. Assim, tiveram como maiores vítimas a) Partidos dos Trabalhadores - alijado do poder pelo golpe jurídico-parlamentar que afastou Dilma Rousseff e o PT da presidência; b) movimento sindical escanteado pela Reforma Trabalhista, promovida nos primeiros meses do governo Temer (2016-2018) e que tira o protagonismo de negociação dos sindicatos sob os acordos e convenções coletivas; mas, principalmente, c) a classe trabalhadora de conjunto, afinal a ofensiva neoliberal promovida nos últimos tem como objetivo claro reduzir o valor pago pelo trabalho no Brasil - há de se fazer uma ressalva importante, dentro da classe trabalhadora, em especial, aos setores oprimidos (mulheres, negrxs e LGBTs) que são os mais atingidos, principalmente, após a eleição de Bolsonaro.

\section{REFERÊNCIAS BIBLIOGRÁFICAS}

BASTOS, P. P. Z. Ascensão e crise do governo Dilma Rousseff e o golpe de 2016: poder estrutural, contradição e ideologia. Revista de Economia Contemporânea, v. 21, pp. 1-63, 2017.

BOITO, A.; MARCELINO, P.; O sindicalismo deixou a crise para trás? Um novo ciclo de greves na década de 2000. CADERNO CRH, Salvador, v. 23, n. 59, pp. 323-338, Maio/Ago. 2010. 
BOITO JR., A.; GALVÃO, A.; MARCELINO, P. R. P. . La nouvelle phase du syndicalisme brésilien. Cabiers des Amériques Latines (Paris), v. 80, pp. 145-164, 2015.

BOITO JR., A. Reforma e crie política no Brasil - os conflitos de classe nos governos do PT. Campinas e São Paulo: Editora Unicamp e Editora Unesp, 2018.

BRAGA, R. A política do precariado: do populismo à hegemonia lulista. São Paulo, SP: Boitempo, 2012.

BRAGA, R. A pulsão plebeia: trabalho, precariedade e rebeliões sociais. São Paulo, SP: Alameda, 2015.

BRAGA, R. Os sindicatos no governo Lula. Le Monde Diplomatique Brasil. Disponível em http://www.diplomatique.org.br/artigo.php?id=683, consultado em 7 de julho de 2016.

BRASIL. Lei 11.648, de 31 de março de 2008. Leis das Centrais Sindicais, Brasília, DF, março de 2008.

CAMPOS, C. Conflitos trabalhistas nas obras do PAC: o caso das Usinas Hidrelétricas de Jirau, Santo Antônio e Belo Monte. Dissertação de Mestrado. IFCH-UNICAMP, 2016.

CARDOSO, A. M. A década neoliberal e a crise dos sindicatos no Brasil. São Paulo, SP: Boitempo, 2003.

CASTELO, R. O novo desenvolvimentismo e a decadência ideológica do pensamento econômico brasileiro. Serviço Social \& Sociedade, São Paulo, n. 112, pp. 613-636, out./dez. 2012.

DIEESE. A situação do Trabalho no Brasil na primeira década dos anos 2000. São Paulo: DIEESE, 2012.

DIEESE. Estudos e Pesquisas, n. 79: Balanço das greves em 2013, 2015

DIEESE. Estudos e Pesquisas, n. 80: Balanço das negociações salariais em 2015, 2016.

DIEESE. Anuário da saúde do trabalhador. São Paulo: DIEESE, 2016. 
DIEESE. Nota técnica: Balanço das negociações dos reajustes salariais de 2016, 2017.

DOMINGUES, J. M. A conjuntura em duas durações: da crise à disputa do futuro. Trincheiras, pp. 5-7, 15 abr. 2015.

DRUCK, G. Os sindicatos, os movimentos sociais e o governo Lula: cooptação e resistência. Osal, ano vi, 19: 329-340, 2006.

DRUCK, G; FILGUEIRAS, L. Política social focalizada e ajuste fiscal: as duas faces do governo Lula. Rev. katálysis [online]. 2007, vol. 10, no.

GALVÃO, A. A CUT na encruzilhada: dilemas do movimento sindical combativo. Idéias, Campinas, v. 09, 2003.

GALVÃO, A. A reconfiguração do movimento sindical nos governos Lula. In: BOITO, A; GALVÃO, A. (Org.). Política e classes sociais no Brasil dos anos 2000. São Paulo, Alameda, 2012, pp. 187-221.

GALVÃO, A.; LEMOS, P. R.; GONCALVES, T. Conlutas e Intersindical: um sindicalismo de funcionários públicos? In: RODRIGUES, F; NOVAES, H.; BATISTA, E. (Org.). Movimentos sociais, trabalho organiz̧ado e educação para além do capital, 2012.

GALVÃO, A. A contribuição do debate sobre a revitalização sindical para a análise do sindicalismo brasileiro. Critica Marxista (São Paulo), v. 38, pp. 103-117, 2014a.

GALVÃO, A. O sindicalismo enquanto movimento social: enfrentando rupturas e dicotomias. In: $38^{\circ}$ Encontro Nacional da ANPOCS, 2014, Caxambu. GT 14 entre as ruas e os gabinetes: institucionalização e contestação nos movimentos sociais latino-americanos, 2014b.

GALVÃO, A., et al. As novas centrais sindicais brasileiras. Curitiba, Appris, 2015.

IPEA. Mercado de trabalho nos anos 90: fatos estilizados e interpretações. Brasília: Ipea, 2010. 
LEMOS, P. R. Entre o mercado e a sociedade: o sindicalismo da União Geral dos Trabalhadores (UGT). Dissertação de Mestrado. IFCH-UNICAMP, 2014.

MARCELINO, P. Sindicalismo e neodesenvolvimentismo: analisando as greves entre 2003 e 2013 no Brasil. Tempo Social, v. 29, pp. 201-227, 2017.

MARTINS, H. H. T. S.; RODRIGUES, I. J. O Sindicalismo Brasileiro na Segunda Metade dos Anos 90. Tempo Social. Revista de Sociologia da USP, São Paulo, v. 11(2), n.2, pp. 155-182, 1999.

MATTOS, M. B. A CUT hoje e os dilemas de adesão à ordem. Revista Outubro, 9: 57-75, 2003.

MATTOS, M. B. As lutas da classe trabalhadora no Brasil dos "megaeventos". OS AL, Argentina, núm. 36, 2014.

MATTOS, M. B. Novas formas de protesto social e velhos caminho de luta da classe trabalbadora: encontros e desencontros. Um estudo a partir do caso brasileiro recente. In: CORBERA, M. M.; SAMPERE, X. D.; MUNTADA, R. M. (Org.). III International Conference Strikes and Social Conflicts: Combined historical approaches to conflict. Barcelona: Proceedings, pp. 1140-1152, 2016

MEDONÇA, M. A. A influência das manifestações de junho de 2013 nas lutas e greves de trabalhadores sindicalizados de São Paulo. Relatório de Iniciação Científica (FAPESP). FFLCH-USP, 2017.

OLIVEIRA, F; BRAGA, R.; RIZEK, C. Hegemonia às avessas: economia, política e cultura na era da servidão financeira. São Paulo, SP: Boitempo, 2010.

OLIVEIRA, F. Crítica à razãa dualista/O ornitorrinco. São Paulo, Boitempo, 2003.

OLIVEIRA, R.V. Sindicato Cidadão: Novos Rumos do Sindicalismo Brasileiro?. Oficina do Ces, Coimbra, n.166, pp. 01-22, 2002. 
OLIVEIRA, R.V.; BRIDI, M. A.; FERRAZ, M.O sindicalismo na era Lula: paradoxos, perspectivas e olhares. Belo Horizonte, MG: Fino Traço, 2014.

PAC, Comitê Gestor do PAC. Lançamento PAC 2, 2010.

PIMENTEL JR., J. Impeachment, oposição e autoritarismo - o perfil e demanda dos manifestantes em São Paulo. Em debate: Belo Horizonte. v.7, n.2, pp.15-22, abr. 2015.

POCHMANN, M. Nova Classe Média? O trabalho na base da pirâmide social brasileira. São Paulo: São Paulo, 2012.

SINGER, A. Os sentidos do lulismo. São Paulo, Companhia das Letras, 2012

SINGER, A. O lulismo em crise: o quebra-cabeça do período Dilma (2011-2016). São Paulo: Companhia das Letras, 2018.

SOARES, J. L. As centrais sindicais e o fenômeno do transformismo no governo Lula. Revista Sociedade e Estado, 28 (13): 541-564.

SÓRIA e SILVA, S. Interseç̧ão de classes: fundos de pensão e sindicalismo no Brasil. Campinas, tese de doutorado em Sociologia, IFCH-UNICAMP, 2011.

TRÓPIA, P. Força Sindical: política e ideologia no sindicalismo brasileiro. São Paulo: Expressão Popular, 2009.

VOLPON, T. Brazil: Dilma 2.0. Nomura Economic Insights: Emerging Markets. Global Markets Research, 2014.

Texto recebido em 16/02/2019 e aprovado em 06/03/2019 
